\title{
Socio-Economic Impact of Tarring the Cameroon Section of the Lagos-Mombasa Trans African HighWay through Mamfe in Manyu Division
}

\author{
Elvis Kah*, Gregory Ndip Bate \\ Department of Geography, University of Yaounde I, FALSS, Yaounde, Cameroon \\ Email: *kah_elvis@yahoo.fr
}

How to cite this paper: Kah, E., \& Bate, G. N. (2020). Socio-Economic Impact of Tarring the Cameroon Section of the Lagos-Mombasa Trans African HighWay through Mamfe in Manyu Division. Open Journal of Social Sciences, 8, 393-411. https://doi.org/10.4236/jss.2020.88033

Received: July 7, 2020

Accepted: August 25, 2020

Published: August 28, 2020

Copyright $\odot 2020$ by author(s) and Scientific Research Publishing Inc. This work is licensed under the Creative Commons Attribution International License (CC BY 4.0).

http://creativecommons.org/licenses/by/4.0/ (c) (i) Open Access

\begin{abstract}
The town of Mamfe in Manyu Division used to be an important socio-economic and political hub in former British Southern Cameroons, and the then West Cameroon geo-politics. Shortly after independence and reunification, it became noticeably clear that the town had switched from relative to absolute decline. This was so because the economic capital of the territory at the time had moved east from Lagos to Douala. Its derelict social infrastructure and road network that ensued from its absolute decline contributed in plunging the town and the entire division into inaccessibility and enclavement. The tarring of the Cameroon section of the Lagos-Mombasa Trans African HighWay (TAHW) came as a long awaited relief to the Manyu people. It opened up not only this region and the backside of this part of the country, but revamped and restored the lost glory Mamfe town once enjoyed. This study aimed at evaluating impact of the TAHW on the socio-economic and environmental development of Mamfe town in particular and Manyu Division in general. The method employed to achieve the desired results combined both secondary and primary sources of data collected from the field, the topographic map of Mamfe and the population data for 2005. Field observations, interviews, administration of questionnaire to randomly selected road construction workers, company officials, administrative officers, elites, politicians, and the local population characterised the data collection. The results revealed that with the tarring of the TAHW across Mamfe, the socio-economic and physical transformation was visible just for one year. Internal and external mobility was not only faster but at cheaper rates too. Small businesses expanded; customs revenue was collected at Ekok qua-doubled and Mamfe became an important centre for many socio-cultural and political activities. The Anglophone
\end{abstract}


crises that sparked off in the latter half of 2016 halted all these achievements.

\section{Keywords}

TAHW, Transformation, Economy, Decline, Growth, Mamfe, Cameroon

\section{Introduction}

Transport is a vital asset to a country's development. Africa has set up programmes to dis-enclave communities in order to trigger country development and progress. Many countries and economic development blocs initiate actions for the construction of major transport highways in order to accomplish the broad base objective for the infrastructural development of Africa. A highway is a main road or a most direct motorable way linking two important areas (Wikipedia, 2013). The classic definition of highway is that it is a main road with many lanes that can go from two to ten depending on the intensity of traffic or the economic situation of the localities they serve. Vehicles moving at relatively high speeds of 120 to $180 \mathrm{~km} / \mathrm{h}$ often mark highways. Unlike secondary roads where the speeds are relatively lower, vehicles plying highways are not expected to halt and pick up passengers, load or discharge loads, except in the face of mechanical break-down or an obstacle.

The main objective of development planners on the African continent was to construct road highways linking the capital states of member countries. The carving out of the continent into regional blocs aimed at attaining the objective of a holistic development (EU's European Development Fund for ACP Group of States, 2012). This laudable initiative to construct road highways that could dis-enclave the entire continent witnessed some feet dragging by most leaders who wanted to maintain their microstates. This significantly retarded the speedy realization of the Trans-African HighWays (TAHW) project. Projects to construct road highways in Africa greatly succeeded in countries of the Maghrebian bloc, the Southern and Western blocs, although this mostly limited to the coastal regions. The vast Sahara Desert and much of the dense equatorial forest of central Africa are lagging behind the attainment of this continental project geared towards the infrastructural development of Africa (ADB/UNECA, 2003). Cameroon that hosts two of these TAHWs (Lagos-Mombasa and Tripoli-Windhoek (Capetown) also witnessed most of its sections not tarred until recently. The Bamenda-Ekok section via Mamfe $(179 \mathrm{~km})$ earmarked in the 1990s as part of the Lagos-Mombasa TAHW remained untarred until 2010. This greatly impeded the economic spring up for the town of Mamfe, its dependent settlements and across the border with Nigeria. To construct the TAHW in Cameroon was to de-block the impasse created at reunification with Cameroon and thus re-boost the lost commercial and economic linkages Mamfe long enjoyed with Nigeria. The lack of a permanent motorable way from Mamfe to Nigeria and to the rest 
of Cameroon prior to the TAHW restrained socio-economic activities at the borders. This strengthened dealings with both the Naira and the FCFA. The construction of the TAHW from Bamenda via Mamfe to across the border to Nigeria has brought back Mamfe town to once more an economic hub thereby boosting economic ties between Cameroon and Nigeria. This however has both positive and negative impacts on the socio-economic and political life of Mamfe which this study seeks to investigate (UNESC, ECA, 2009).

Before independence and the reunification of West Cameroon with East Cameroon, the town of Mamfe in Manyu Division happened to be an important political and economic hub of former West Cameroon geo-politics. After the independence and reunification, the buoyant relationship that this town enjoyed with Nigeria dwindled considerably. Its socio-economic relationship with the then East Cameroon did not experience the highly expected boom either. Even the indigenes of Manyu shied away from its development since development had moved east from Lagos to Douala (Ndi, 2013a, 2013b). Shortly after independence and reunification, it became noticeably clear that the town had switched from relative to absolute decline. This was so because the economic capital of the territory at the time had moved east from Lagos to Douala. Its derelict social infrastructure and road network that ensued from its absolute decline contributed in plunging the town and the entire division into inaccessibility and enclavement. The tarring of the Cameroon section of the Lagos-Mombasa Trans African HighWay (TAHW) came as a long awaited relief to the Manyu people. It opened up, not only this region and the backside of this part of the country, but also revamped and restored the lost glory Mamfe town once enjoyed (Enoh Oben, 1987).

There are often four main modes in the transport sector which include road, air, maritime and rail modes. Road transport remains the main mode in sub-Sahara Africa which this study focused on. Railways were developed during the colonial period but almost abandoned since the independence in most countries. Air transport once seen as sign of economic prosperity and instrument of sovereignty is far from being competitive. Maritime transport is mainly on coastal areas, and still controlled by foreign companies. In this context, road transport, favoured by the low purchasing power of the population and the geography of the continent, in landlocked territories, becomes the main mode of transportation. This mode, however is facing many challenges: poor maintenance, pollution, frequent accidents, lack of local industry, etc. This is the reason Teravaninthorn and Raballand (2009) state that transporting goods through the road are very costly and this constitutes the major obstacle to the economic growth of these countries. Taking the example of three French speaking countries in Africa (Cameroon, Cote d'Ivoire and Mali) these authors state that the cost of transporting goods in these countries is six times higher than Pakistan and about $40 \%$ higher than in France. Reasons they advanced for this are that there is low productivity in the trucking industry, low competition between service providers 
and poor state of road infrastructure.

Gina Porter (2012) in assessing the impact on the rural poor of constructing roads in Ghana and Nigeria, this author focused on women since women experience more poverty than men, a situation that prevails in Manyu Division. They are the main farmers producing foodstuffs that are sold in the markets. He concludes that roads in West Africa are not necessarily a good thing for women who live by them. This is because they are often not in a position to take advantage of the benefits that the roads confer. That for women and other sectors of the rural poor who live away from good roads, regional road construction programmes can even make life harder. All the benefits of the TAHW in Manyu Division as investigated in this study lasted just for one year.

\section{Materials and Methods}

\subsection{The Study Area}

Mamfe town is the headquarters of Manyu Division that is made up of four Sub-divisions; Mamfe Central, Eyumojock, Akwaya and Upper Bayang. It lies approximately between longitudes $8^{\circ} 40^{\prime}$ and $9^{\circ} 20^{\prime}$, east of the Prime Meridian and latitudes $5^{\circ} 05^{\prime}$ and $6^{\circ} 10^{\prime}$ north of the equator (Figure 1 ). Its oval shape thrusts it out north-west ward from Ndian in the south making it a wedge between west and central Africa. This shape imposes upon it an international boundary, which it shares with the Federal Republic of Nigeria to the west. In the north east, it is bounded by the North West Region, to the south by Meme and Ndian Divisions in the South West Region of Cameroon.

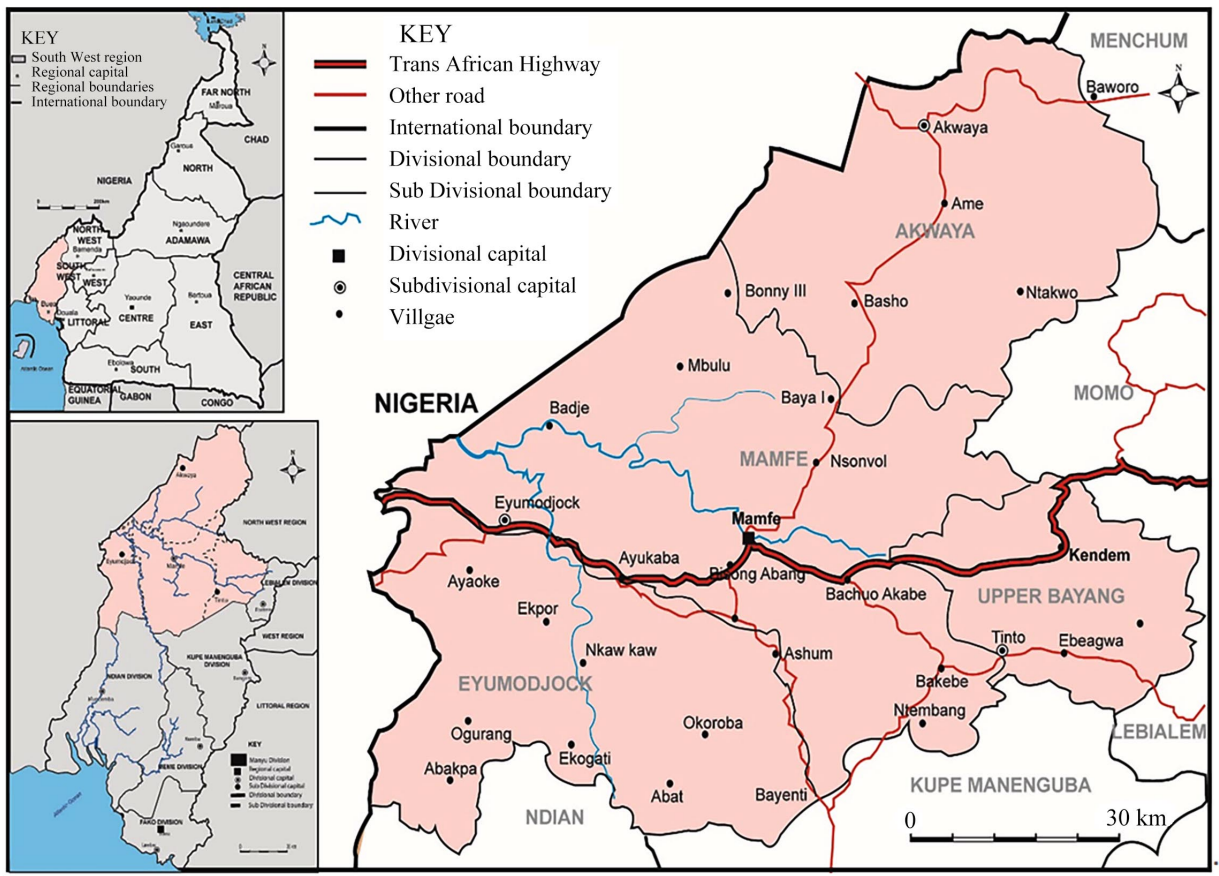

Figure 1. Location of Mamfe in Manyu Division, south west region of Cameroon. Source: Adapted from the Cameroon Administrative map of 1992. 
Being one of the oldest divisions, Manyu was the hub of economic activities in the then Southern Cameroons from the late 1950s to the beginning of the 1960s as all its socio-economic and political life was linked to Nigeria. When this territory joined the Republic of Cameroon through a UN organised Plebiscite in 1961, its status as a federal state run from Buea (Federal capital of West Cameroon) did not change much though this socio-economic and political life became linked to the Republic of Cameroon. The trunk A road that linked Victoria via Buea, Kumba, Mamfe, Bamenda, Kumbo, Nkambe, Wum and back to Bamenda constituted the life wire of the then West Cameroon economy. The bifurcation in Mamfe (i.e. to Ikom in Nigeria), which hitherto served as the main link between Southern Cameroons and Nigeria made Mamfe and economic centre. When the federal system in Cameroon was abolished in 1972 and the institution of a unitary state, all efforts to maintain and or develop these roads were futile. The town of Mamfe became relegated to the backyard, as it became a near island with the dilapidation of the Mamfe-Kumba, Mamfe-Bamenda and Mamfe-Ekok roads. With the tarring of these roads as from 2010, Mamfe once more resurfaced as an emerging economic centre, which thus motivated this study (Achankeng, 1995).

\subsection{Methods and Techniques}

\subsubsection{Data Collection}

This study made use of a number of materials and methods for the attainment of the expected results. Field observations made on the physical and human landscape before, during and after the tarring of the TAHW were to appreciate the socio-economic and political mutations that cropped up. This then followed with interviews of administrative officials, staff of the road construction company as well as the local population, chiefs and quarter heads. This was to assess the impact of the TAHW on the socio-economic and political life styles of the people of Mamfe town and the rest of Manyu Division. Organised focus group discussions took place in three different sites. This first targeted the officials of the road construction company on statistical issues such as the total length of the road, the total number of workers employed, salary paid per worker etc. The second site targeted economic operators and local NGOs on nascent economic activities in the area due to the TAHW, profits and volume of sales. The third focused on group discussions held with administrative officials to assess the level of insecurity in the study area. The researchers took photographs on important socio-economic activities in the study area. Finally, a set questionnaire was administered to the population, which contained both closed-ended and open-ended questions. This was necessary for qualitative and quantitative interpretation and analysis of the data collected.

The method adopted to this study is the hypothetical-deductive method (Everson et al., 1972). The first phase of data collection constituted of bibliographic research while the second phase was fieldwork. Bibliographic research permitted the consultation of archival documents from the Mamfe Urban council and docu- 
mentation centres in Manyu Division and Buea. From these documentation centres, information related to transport development, impact of road construction on socio-economic and political development was explored and analysed.

\subsubsection{Sampling Techniques of the Population}

The total human population for Manyu division for 2020 stands at 235,145 inhabitants (projected RGPH of 1987 and 2005) using this formula,

$$
P_{x}=P_{1}+\frac{N}{n}\left(P_{2}-P_{1}\right)
$$

where $P_{x}$ is the projected population, $N$ is the period between $P_{1}$ and $P_{x}, n$ is the period between $P_{1}$ and $P_{2}, P_{1}$ is the initial population and $P_{2}$ is the last known population.

The population for the three Subdivisions excluding Akwaya for which our study bases stands at 95,125 inhabitants. This population unevenly lives in 235 villages constituted in 30,625 households who in one way or the other have something to do with the Trans African HighWay. Of the three sub Divisions, the study focused on seven village groupings with each grouping having a number of villages that made up the 235 villages (Table 1 ).

The sample size for this study was selected from the households. The reason for using households was that it is much easier to administer a questionnaire with them than to individuals among the population. Anybody within a household can respond to questions unlike to individuals who at one moment or the other can be absent thereby prolonging the period meant from the questionnaire administration. Effectively, $2 \%$ of these households were decided upon to constitute the sample size. The rationale for selecting a $2 \%$ sample ties to what Nwana (1982) postulated. The villages retained for the study were chosen from the three sub divisions where the TAHW passes through. They include Upper Bayang, Mamfe central and Eyumojock Subdivisions. Table 2 summarises the technique used in administering the questionnaire in the field.

The random sampling technique was used because of a few reasons. The houses in the study area are not numbered, so total number of houses in the study area is unknown. Some of the settlements stretch along the TAHW while others scatter in the forest in small nuclei. Four field assistants were recruited to assist in the administration of the questionnaire. These field assistants are young men who master the territory, the culture i.e. the Ejagham and Keaka languages and could testify for themselves life before and after the TAHW.

Difficulties faced in the data collection included accessibility as some villages such as Babong, Eyang and Fayib are very far from the TAH and joined by very poor and highly seasonal roads. Secondly, some of the respondents demonstrated scepticism in providing ample information especially on the bias nature of compensations made on property destroyed during the construction of the TAHW. 
Table 1. Population and household numbers in Manyu Division.

\begin{tabular}{lllll}
\hline Sub division & Village & Population 2005 & Population 2020 & Households \\
\hline Upper Bayang & -Kendem & 27,485 & 33,624 & 4870 \\
Sub total & 65 & 27,485 & 33,624 & 4870 \\
Mamfe central & $\begin{array}{l}\text {-Mamfe town } \\
\text {-Bachuo Akagbe }\end{array}$ & 31,641 & 42,006 & 6863 \\
Sub total & -Besongabang & & & \\
Eyumojock & 17 & 31,641 & 42,006 & 6863 \\
Sub total & -Eyumojock & & & \\
Total & - Ayukaba & 35,999 & 46,513 & 18,892 \\
\hline
\end{tabular}

Source: (BUCREP, 2005).

Table 2. Population sample size (households).

\begin{tabular}{ccccc}
\hline Sub division & Villages & Households & 2\% sample size (household) & Effective respondents \\
\hline Upper Bayang & 65 & 4870 & 94 & 53 \\
Mamfe central & 17 & 6863 & 137 & 105 \\
Eyumojock & 153 & 18,892 & 378 & 250 \\
Total & 235 & 30,625 & 609 & 408 \\
$\%$ & 100 & 100 & 2 & 67 \\
\hline
\end{tabular}

Source: Computed from Table 1.

\subsection{Data Treatment}

Data collected from various sources especially from the questionnaire administration were analysed to produce various illustrations for better understanding. More precisely, descriptive statistics were used to analyse and interpret the results deduced from field investigation.

Data treatment was synthesized with the guide of concepts and theories. The information gathered on the field yielded both qualitative and quantitative data. The tools employed for data analysis include descriptive statistics such as tables, percentages, pie charts and bar charts. The following softwares and programmes constituted the treatment and analysis of data collected from the field. These include Map source, ARC GIS 10.0, and Microsoft Word Arc GIS 10.0 and Adobe Illustrator. Following the simplest procedure, some points and other elements were collected in the area using a GPS; other elements were collected by field inquiry. Most of the work was done through the digitization of elements on the field for example; surface figures such as houses and habitat digitalized in the form of polygon, linear figures such as water courses and the road networks in the form of poly-line and punctual figures digitized using points. In this light, several layers in the software emerged for different purposes and use. Once all these elements were regrouped on a map, several parameters and techniques 
were applied for its accomplishment.

\subsection{Data Analysis}

It was necessary because it provided an opportunity for the researcher to examine, analyse and interpret the data collected and treated. In so doing, recourse focused on the use of social science statistical tools of analyses such as Microsoft excel 2010, Microsoft word and SPSS Statistics 20. SPSS statistics 20 enabled the crossing of this data that eventually produced frequency tables and charts that articulated on the link between the passing of the Trans African HighWay through Manyu and the socio-economic impact.

\section{Results}

\subsection{Improved Internal and External Population Mobility}

Internal mobility in Manyu Division involves the displacement of people on relatively short distances such as from one subdivision to the other, from one village to the other or from one compound to the other in the same village. However, the tendency is that they remain within a familiar cultural environment and therefore have few problems of adjustment to language, social customs, ideology and institutions. Though the constraints to internal migration include low incomes, family wrangling, settling of scores and deplorable road infrastructural network, the construction of the TAHW has mitigated these constrains and further boosted the propensity to mobility from one place to the other. This is simply because transport fares, especially along the TAHW dropped tremendously with no seasonal variation as was the case before (Ngwa Nebasina, 1997).

Before the tarring of the TAHW, Manyu Division in general and Mamfe in particular appeared more as an island, as movements of goods and people were too limited. During the rainy season, trade between the adjacent rural communities with Mamfe town and across to Nigerian was near inexistent. Table 3 reveals a wide disparity of transport fares from one season to the other in displacing within or without the division. The deplorable nature of the road network at the time, coupled with the inaccessibility of some places triggered a hike in transport fares during the rainy season as opposed to the dry season. This discouraged many people from travelling and from trading (Teravaninthorn \& Raballand, 2009).

The tarring of the TAHW has opened up this area to various socio-economic opportunities as many transport agencies have opened up agencies in Mamfe town. These include agencies such as MOGHAMO, VATICAN, MONDIAL, GOLDEN and MUSANGO bringing buses with 70 seats capacity for inter-urban transportation. Due to the tremendous increase in passengers, these travelling agencies operate at same and different itineries as illustrated by Table 4 and Figure 2. Furthermore, the tarring of the TAHW came along with the setting up of public and private building infrastructures for collective and private purposes. 
Table 3. Seasonal variation in transport fares before and after the construction of the TAHW in Manyu Division.

\begin{tabular}{cccccc}
\hline Seasons & Departure & Destination & $\begin{array}{c}\text { Distance } \\
\text { (in km) }\end{array}$ & $\begin{array}{c}\text { Amount (in FCFA) } \\
\text { before the TAHW }\end{array}$ & $\begin{array}{c}\text { Amount (in FCFA) } \\
\text { with the TAHW }\end{array}$ \\
\hline \multirow{2}{*}{ Wet } & Mamfe & Ekok & 65 & 10,000 & 5000 \\
& Kumba & Mamfe & 85 & 5000 & 1000 \\
& Bamenda & Mamfe & 114 & 15,000 & 8000 \\
& Mamfe & Ekok & 65 & 6000 & $2500-3000$ \\
& Eyumojock & Ekok & 23 & 6000 & 5000 \\
& Kumba & Mamfe & 85 & 3000 & 1000 \\
& Bamenda & Mamfe & 114 & 8000 & 5000 \\
\hline
\end{tabular}

Source: Fieldwork, 2018.

Table 4. Average number of passengers transported per day.

\begin{tabular}{|c|c|c|c|}
\hline $\mathrm{N}^{\circ}$ & Travel Agency & Itinery & $\begin{array}{l}\text { Number of passengers } \\
\text { per day (to and fro) }\end{array}$ \\
\hline \multirow{2}{*}{1} & \multirow{2}{*}{ Alibaba Express } & -Mamfe-Kumba-Limbe & 910 \\
\hline & & -Mamfe-Bamenda & 815 \\
\hline \multirow{3}{*}{2} & \multirow{3}{*}{ Moghamo Express } & -Mamfe-Bamenda-Yaounde* & 320 \\
\hline & & -Mamfe-Kumba-Douala & 450 \\
\hline & & -Mamfe-Bamenda-Douala ${ }^{* * *}$ & 380 \\
\hline \multirow{2}{*}{3} & \multirow{2}{*}{ Symbol of Unity Express } & -Mamfe-Kumba & 278 \\
\hline & & -Mamfe-Bamenda & 165 \\
\hline \multirow{3}{*}{4} & \multirow{3}{*}{ Vatican Express } & -Mamfe-Bamenda-Yaounde & 280 \\
\hline & & -Mamfe-Ekok & 160 \\
\hline & & -Mamfe-Bamenda-Douala & 158 \\
\hline \multirow{3}{*}{5} & \multirow{3}{*}{ Mondial Express } & -Mamfe-Ikom-Enugu-Onitsha & 140 \\
\hline & & -Mamfe-Kumba-Yaounde & 110 \\
\hline & & -Mamfe-Kumba-Douala & 88 \\
\hline
\end{tabular}

${ }^{\star}$ Bamenda-Yaounde excluded, ${ }^{*}$ Kumba-Douala excluded, ${ }^{* * * B a m e n d a-D o u a l a ~ e x c l u d e d, ~ S o u r c e: ~ F i e l d-~}$ work 2018.

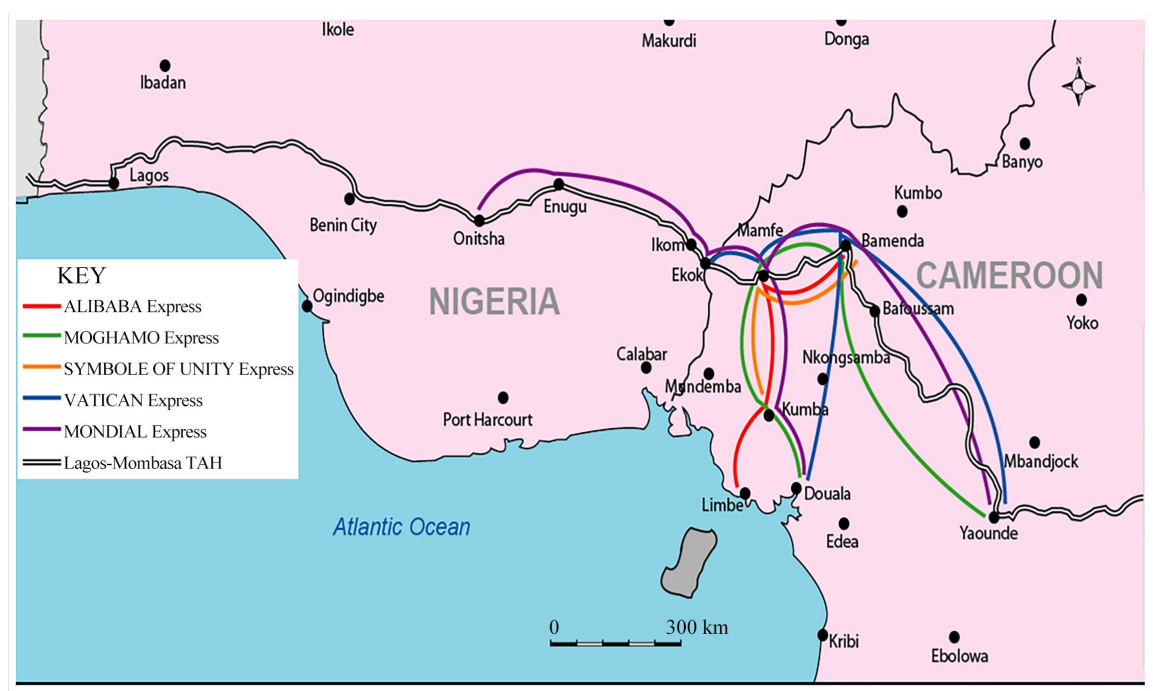

Figure 2. Operation lines of the travelling agencies stationed in Mamfe. 
The flux of passengers has more than doubled with the tarring of the TAHW through Mamfe. Now people have to travel in and out of Manyu Division conveniently and at cheaper transport fares. ALIBABA Express that was the lone agency before the tar has marked the Manyu man. Though this agency operated with mini buses (14 seater, 18 seater and 30 seater buses), it did not lose its clients to new arrivals. When tar arrived, coupled with the arrival of other travelling agencies with more comfortable buses of higher capacities (53 seater, 60 seater and 70 seater buses), this only solved the problem of increased flux of passengers. Most of the local population remained glued to the agency that cooperated with them during the difficult days. It is for this reason that ALIBABA Express still top the list in the number of passengers transported per day to and from Mamfe as seen in Table 4. Being its major line from creation, this travelling agency has won the hearts of the Manyu man as both are manifesting mutual trust (O’Kelly, 1998).

This increased mobility of people is for various reasons. Firstly, it is for religious purposes, as Mamfe town in particular has of late become a centre for religious activities due to its geographical location. Church and ecumenical services have been organised there to pray for peace for both Nigeria and Cameroon. Christians congregate there on annual basis coming from cities such as Bamenda, Kumba, Douala, Yaounde etc. on the side of Cameroon and from Ikom, Calabar, Onitsha, Lagos, Enugu, Jos, Ibandan etc. on the side of Nigeria. These prayers that hold at the town's Ground Stand, mostly centre on the outbreak of the Ebola disease in DR Congo and the Boko Haram threats in the north that affects Nigeria and Cameroon. This brings together many religious leaders of different denominations, which include the Pentecostants, Protestants and Roman Catholics (Donaldson, Jinhage, \& Verhoogen, 2017).

Furthermore, Mamfe has also become a transit town for Christians on pilgrimage for religious purposes to and from Nigeria. Noteworthy is that Nigeria of late has become famous in organising Divine Healing Services, which attract Christians from all over the world. The tarring of the TAHW makes Mamfe the easiest transit corridor from Cameroon to Nigeria thus giving a facelift of the town in handling a higher influx of religious pilgrims (Cupers \& Meier, 2020).

\subsection{Setting Up of Many Businesses}

To demonstrate the economic twist due to the advent of the TAHW, many economic establishments in Cameroon now consider Mamfe a potential market centre. For example, CONGELCAM, the main dealer in frozen fish in the country opened a branch in the town of Mamfe in 2015. This has not only facilitated the acquisition of fresh fish at all times, but has spurred other related fish businesses such as the roasting of fresh fish around bars, snacks, off-licenses and nightclubs that have cropped up to handle the teeming population, a phenomenon that never existed before. CONGELCAM has led to the phenomenon of fish retailers who supply to surrounding villages at all times. These villages hitherto depended 
on fish from the rivers, which was seasonal, and on the ability to catch. Most of the villages such as Kembong, Afab, Besonabang Ossing, Afap have developed hotspots where most young girls (80\% of them not from Manyu Division but from the Bassa tribe in the Littoral Region of Cameroon) employ themselves in roasting fish near the bars.

Again, many depots have seen the light of day in Mamfe. Here we are talking of Brazzerries du Cameroun and Guinness Cameroon SA both being the main beer brewing companies, cement such as CIMENCAM and of recent DANGOTE Cement $S A$, warehouses especially on basic necessities such as sugar, salt, maggi cubes, milk, soja oil, bread matches, etc. and hardware stores for building materials. Either from Kumba or from Bamenda, the good roads make it in such a way that these depots benefit from regular supplies. Retail shops have sprung up within the town of Mamfe and in surrounding villages where they get constant supplies from the depots, which boost the economic transactions in the whole Division. With flour in the depots, bakeries have seen the light of day that even supply bread across the border to Nigeria (Tranche, 2018).

\subsection{Accelerated Cross-Border Trade}

When the oil boom brought Nigerian agriculture to its knees before 1981, Cameroon was the breadbasket to Nigeria and other central African countries. The food deficit later pushed many Nigerians to embark aggressively on agriculture in a bid to meet up with the ever-growing demand for food. From 1980 to 1990, i.e. before the oil boom that crumbled agriculture, many women from Manyu Division, Douala, Nkongsamba, Bafoussam and other areas in Cameroon often crossed over to Nigeria though Ekok to buy foodstuff such as yams, maize, groundnuts, palm oil, tomatoes etc. Major producing areas in Nigeria that were closer to the Cameroon border included Ikom and Ikang. However, the problem of farm to market roads coupled with the poor state of the TAHW at the time did not render the business for foodstuff profitable. This business often went dead during the rainy season, as it was not easy to transport the foodstuff to Cameroon, thus creating artificial scarcity in the markets (Achankeng, 1984). With the Nigerian oil boom, it became a reverse situation which can be termed pendulum cross border trade between Cameroon and Nigeria, wherein at one moment truckloads of a particular good cross from Nigerian to Cameroon and at another moment truckloads of that same good cross from Cameroon into Nigeria (Figure 3).

Sources at the Ekok customs office revealed that, the importation of foodstuff from Nigeria to Cameroon increased from 149.88 tonnes in 2008 to 313.53 tonnes in 2009 giving an increase of 163,65 tonnes. Reason advanced to this was the poor state of the TAHW, which was untarred at the time coupled with poor feeder roads that linked to it. Thus, Mamfe town in particular and Manyu Division in general greatly benefited on cross-border trade with the commencement of work on the TAHW in 2010 (Table 5). 


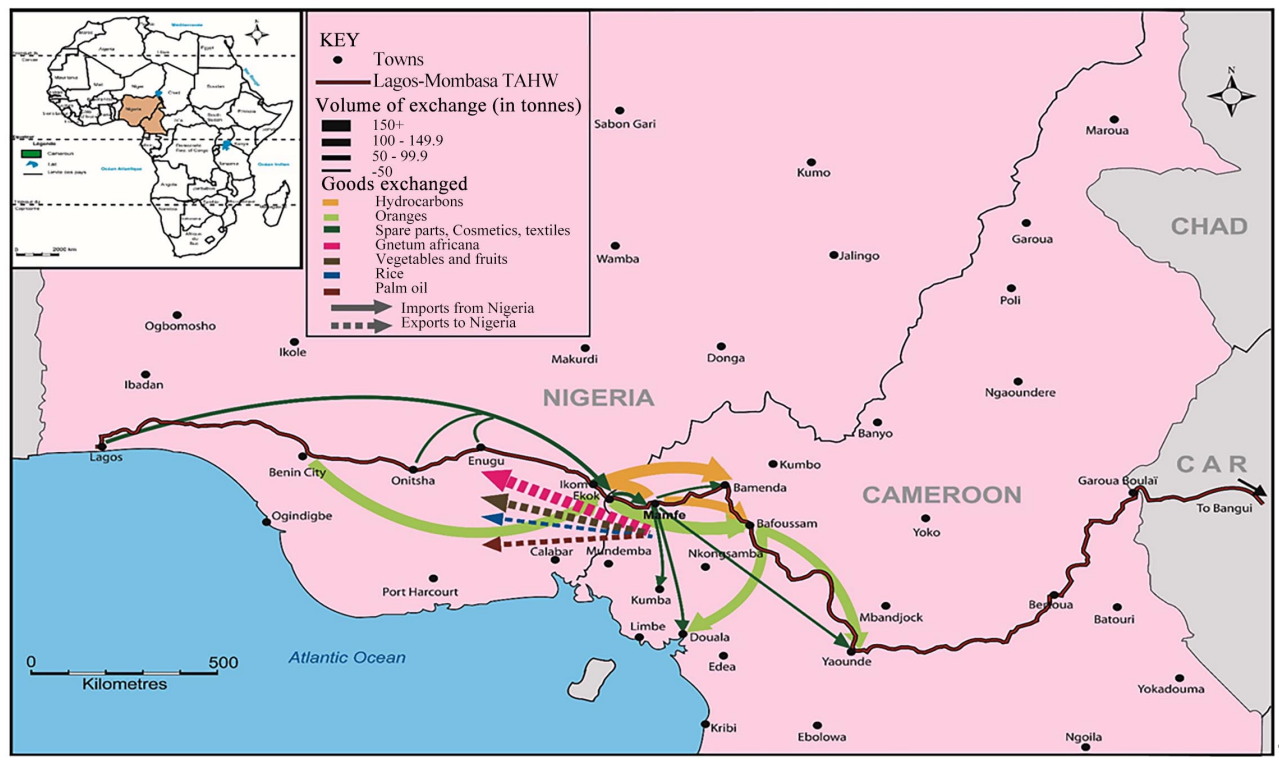

Figure 3. Flux of cross-border trade.

Table 5. Goods on transit at the Ekok frontier market in 2016 (in tonnes).

\begin{tabular}{|c|c|c|c|c|c|}
\hline & Products & $\begin{array}{l}\text { Country of } \\
\text { destination }\end{array}$ & $\begin{array}{c}\text { First } \\
\text { semester }\end{array}$ & $\begin{array}{c}\text { Second } \\
\text { semester }\end{array}$ & Total \\
\hline \multirow{13}{*}{$\begin{array}{l}\text { Primary goods } \\
\text { (Foodstuffs) }\end{array}$} & Gnectum Africana (eru) & Nigeria & 83.8 & 52.2 & 136.0 \\
\hline & Bush mango (irvingia) & Nigeria & 24.90 & 13.11 & 38.0 \\
\hline & Ebuga & Nigeria & 051 & 0.1 & 0.61 \\
\hline & Cola nuts & Nigeria & 8.2 & 1.8 & 10.0 \\
\hline & Plantain & Nigeria & 23.4 & 0 & 23.4 \\
\hline & Pepper & Nigeria & 0.9 & 0.15 & 1.0 \\
\hline & Cocoyams & Nigeria & 26.9 & 22.9 & 49.8 \\
\hline & Carrots & Nigeria & 0 & 0.39 & 0.39 \\
\hline & Cabbages & Nigeria & 0 & 0.65 & 0.65 \\
\hline & Apples & Nigeria & 0 & 0.75 & 0.75 \\
\hline & Rice & Nigeria & 20.0 & 0 & 20.0 \\
\hline & Palm oil & Nigeria & 50.76 & 35.08 & 85.84 \\
\hline & Garri & Nigeria & 7.9 & 1.8 & 9.7 \\
\hline \multirow{7}{*}{$\begin{array}{l}\text { Manufactured } \\
\text { goods }\end{array}$} & Textiles & Cameroon & & & \\
\hline & Cosmetics $^{*}$ & Cameroon & & & \\
\hline & Wine & Cameroon & 0 & 0.20 & 0.2 \\
\hline & Second hand clothes & Nigeria & 19.75 & 23.55 & 43.3 \\
\hline & Electronic appliances ${ }^{\star}$ & Cameroon & & & \\
\hline & Plastics ${ }^{\star}$ & Cameroon & & & \\
\hline & Motor spare parts & Cameroon & 113.16 & 163.53 & 276.69 \\
\hline
\end{tabular}

${ }^{*}$ Quantity not evaluated. Source: Chief of phytosanitary police post Ekok, 2018. 
The increase in cross-border trade also let to a tremendous increase customs revenue. From independence up to the early 1970s, the border town of Ekok remained the highest point where custom revenue was raised in West Cameroon. This position shifted to the third when the federal structure of the country changed to a unitary state. The customs point further relegated due to the dilapidating road for more than two decades i.e. 1990s and 2000s. However, with the tarring of that road, the increase in business transactions across the border pushed up customs revenue, which was a great boost to the Cameroon economy as a whole and that of Manyu Division in particular. At the customs post of Ekok, one finds long queue of 20 - 30 tonnes trucks awaiting clearance. The volume of goods imported and exported on daily basis out strips the customs ware houses, such that clearance are done in the open air. This obliges the customs officials to adopt the Trans-loading-technique system, which enable them handle the daily volume of goods. This technique refers to when the volume of goods are evaluated directly in the truck given the type and nature of goods (Ashu, 2004) (Plate 1).

\section{Analysis}

In general, asphalt pavement materials eliminate potentially dangerous and expensive pavement blow-ups. Smooth asphalt pavements provide a uniform surface for easy navigation by vehicles. Rough and uneven road surfaces increase driver fatigue and diminish control. Defining itineries and tarring the different TAHWs of Africa was an initiative put in place in the 1970s with the creation of the Trans African HighWay Bureau in Lusaka Zambia (Figure 4). Many countries did not adhere to this initiative and in the 1980s; the bureau shot its doors. Reasons advanced to this non-adherence were that, the tarring of roads is purely a national issue and countries do this according to their means, economic interest and norms (Barr et al., 1972).

The tarring of the Bamenda-Ekok via Mamfe section of the Lagos-Mombasa TAHW depended on decision from the central administration in Yaounde. From archives, it is worthy to note that this road had been decreed for tarring by the West Cameroon government based in Buea in the 1960s. However, when the state of West Cameroon was dissolved in 1972 to form a United Republic of Cameroon, this decree seemed to have been abandoned. The new dispensation of categorising roads in Cameroon (National roads, regional roads and rural roads) that followed the French standards, placed this section of the TAHW as National Road No. 6. To that effect, tarring it was not a top priority to the Cameroon government run from Yaounde (Etamba Eta, 1999).

A highly successful idea in the European continent, the TAHW initiative resurfaced in the 2000s, especially with the coming into existence of New Partnership for Africa's Development (NEPAD). Resulting from the fusion of Omega Plan and Millennium African Plan, NEPAD functions under the auspices of the African Union where financial institutions and other development partners 
guarantee allegiance. With a holistic view of dis-enclaving the continent, this body defined the different TAHWs of Africa today and motivates governments in developing their own sections (Adams et al., 2001). Thus, the tarring of the Bamenda-Ekok stretch of the TAHW highly succeeded under external influences, especially with financial assistance from the African Development Bank, European Union and the Islamic Bank.

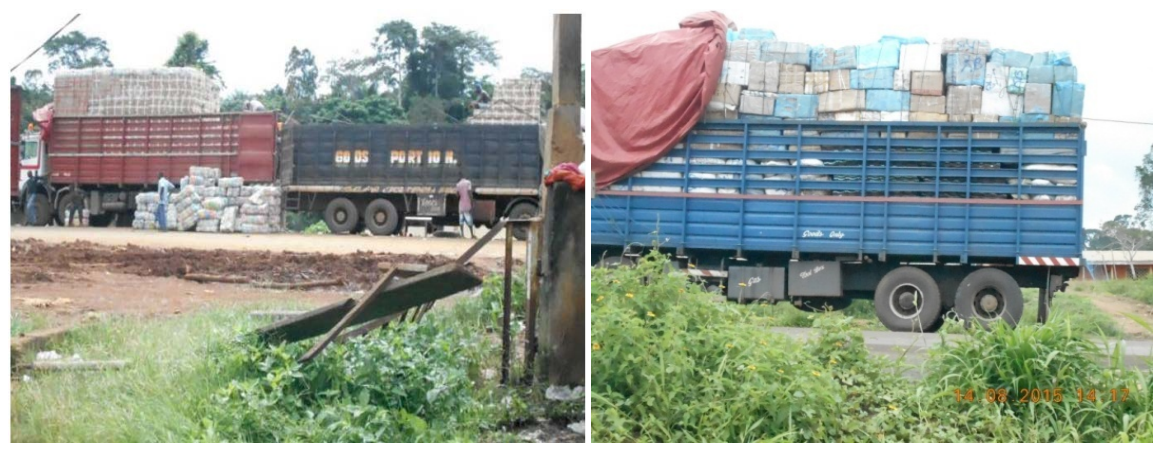

Plate 1. Trucks on transit at the Ekok customs point heading to opposite directions.

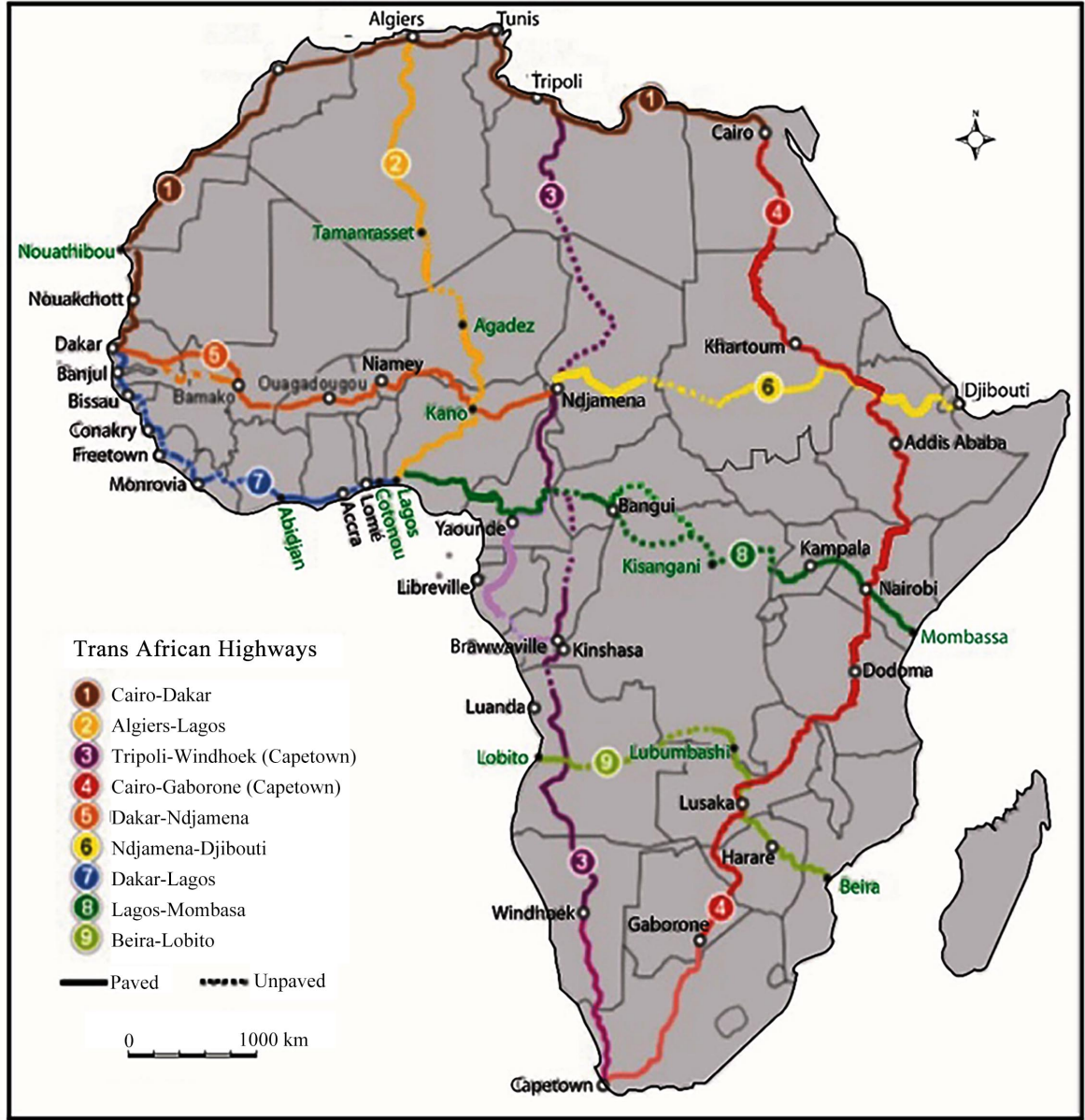

Figure 4. Trans African HighWays defined in africa. Source: Adapted from ADB/UNECA (2003): Review of the Implementation Status of the Trans-African HighWays and Missing Links: Volume 1: Description of Corridors August, 14, 2003, p 58. 
Though a recent phenomenon, the tarring of this road reawakened the Manyu man, journeys are not only faster but at cheaper rates too (Table 3). Many travel agencies have stationed in Mamfe where the town now witnesses decentralised bus stops. At first, certain crowd-pulling activities could never be hosted in Mamfe. Today, the reverse seems to be true as important ecumenical services are organised there. It serves as the prayer ground for the outbreak of the Ebola disease and the Boko Haram insurgence in northern parts of Nigeria and Cameroon. Before the tarring of the TAHW, only one motor park existed and that was besides the Mamfe main market. The decentralised motor parks in the town today (Table 2) is proof of a tremendous increase in passengers.

The presence of the tarred road enhances mobility and revamps the lost glory of Mamfe town. Unfortunately, this situation is compounded with protracted confinement, economic lock down couple with multiple calls for ghost towns brought about by the Anglophone problem that had rocked this part of Cameroon since 2016.

Businesses have sprung up in the whole division. The delivery of goods is now faster to the extent that there is the non-decay of perishable goods. Relatively, business people now realise profits whose multiplier effect is the attraction of more people to take up Mamfe as their permanent resident. In spite of the stability in transport fares throughout the year, the low income of the indigenous population coupled with the strong social ties continue to impede internal and external mobility. However, the influx of people from other parts of Cameroon especially from the Littoral Region is proof of the fact that businesses make profit. Given that most of the new comers are women, they mostly focus on petit trading such as roasting of fish around bars, promiscuity and provision stores. This means that in spite of the tarring of the TAHW, the poverty situation of the Manyu man has not really improved.

Located in a dense forest region, where the relief, fertile soils and climate are appealing, investors in large-scale agriculture are yet to exploit the area. However, with the advent of the TAHW, a majority of the local population remain glued to smallholder farming of food crops largely meant for household consumption. As Figure 6 illustrates, all the settlements adjacent to the TAHW in Manyu Division transport their produce for sale to the tarred roadside. This is for onward transportation to the market either in Nigeria of in Cameroon.

\section{Discussion}

Although it took many years for the Cameroon government to approve the tarring of its section of the Lagos-Mombasa TAHW (2010-2015), there is a strong believe that this depended on national priorities unlike from external influences. Agreeing to this fact, if international financial institutions did not implicate in it, many more years could be needed for the government of Cameroon to realise this project ADB Group (2014). Upon the completion of this road in 2015, alien population flooded the town and scrambled for the acquisition of large expands 
of land on strategic positions for business and plantation agriculture. This was followed by an ephemeral boom in socio-economic activities that later dwindled. What therefore explains this sudden decline in socio-economic activities in the study area? The major reason advanced points to the Anglophone crisis, which started in 2016, barely one year after the completion of the road. This means that all the advantages enumerated above due to the tarring of this road happened within a year. It should be noted that it is in Manyu Division that the crisis turned into an armed conflict. This was followed by consistent calls for ghost towns, civil disobedience and the grounding of the civil service. This has succeeded in scaring away investors and alien population that came to settled there in order to take advantage of the road. Due to this, the development of Mamfe, alongside that of the entire division has reversed to more than what it was prior to the construction of this road. Had it not been for the Anglophone crisis therefore, this study unit area could have got to another significant level of development appreciated by both the local population and economists.

In ignoring all the difficulties involved, farmers channelled their produce to transitional markets along the TAHW (Figure 5), which easily got to the markets either in Cameroon or in Nigeria. Those going to Nigeria must pass through the Ekok frontier market thus subjected to the payment of custom duties. The reverse situation is the same for those coming from Nigeria. This is case of a pendulum border trade as described above (Sera, 1975). This scenario implies that both Cameroon and Nigeria are proficient in agricultural production, but with Cameroon having an absolute advantage over Nigeria. On the other hand, Nigeria also has an absolute advantage over Cameroon in Manufactured Goods as can be noticed at the Ekok customs checkpoint.

Figure 6 shows the rise in customs collection revenue from 2004 to 2016, though real increase began in 2011 (144 million FCFA), the total money collected more than doubled by 2014 (356 million FCFA). By the second quarter of 2016 after the TAHW had been tarred, the amount collected (370 million FCFA) had already surpassed that of 2014, which was the peak level. With this trend, it means that the revenue collected at the Ekok customs post could have qua-doubled by the end of 2016 had it not been the advent of the Anglophone crisis that halted abruptly every sphere of economic life in the zone. This ties to the performance report of Cameroon (MINEPAT, 2010) which states that between 2001 and 2019, total exports in Cameroon generated in average about 530 Billion FCFA. From this figure, the highest amount was obtained in 2011 (3589.80 FCFA) while the lowest was reached in April 2018 (108.32 Billion FCFA) owing to the ongoing crisis that the country is facing. These exports by 2017 generated the total amount of 2500 Billion FCFA (about 4.27 Billion Dollars).

\section{Conclusion}

This study centred on "The socio-economic impact of the construction of the 


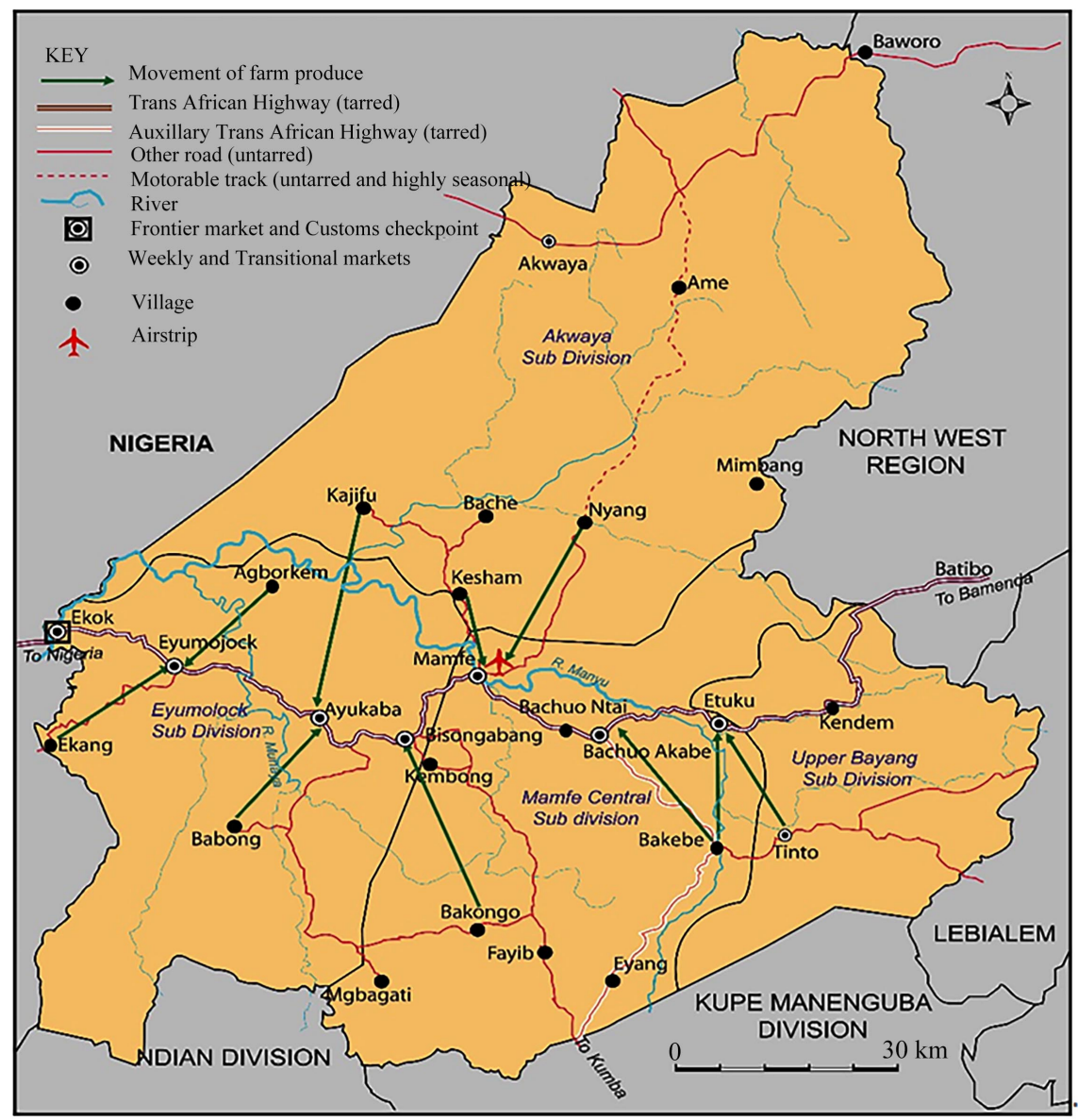

Figure 5. Direction of movement of farm produce towards the TAHW in Manyu Division.

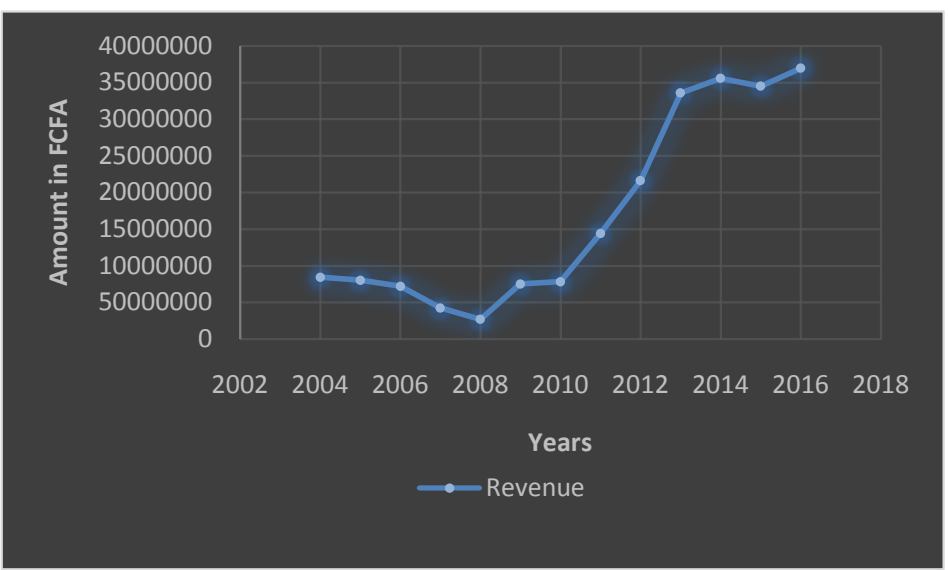

Figure 6. Customs revenue generated at the Ekok customs checkpoint.

TAHW through Mamfe in Manyu Division". Its principal objective was to evaluate the impact of this road in revamping the socio-economic development of Mamfe town in particular and Manyu Division in general. The town of Mamfe had always been an economic hub prior to independence and reunification between east and west Cameroon. This privilege position was lost shortly 
after independence because development had moved east from Lagos to Douala. The government has made some efforts in revamping the lost glory of this important colonial town, but all these achievements could barely be noticed just for one year (2015-2016) until the Anglophone crisis cropped up to mortgage every aspect of benefit registered due to the tarring of the Cameroon section of the Lagos-Mombasa TAHW (Environmental Protection Agency, 1997).

\section{Conflicts of Interest}

The authors declare no conflicts of interest regarding the publication of this paper.

\section{References}

Achankeng, E. (1984). Mamfe. Growth Experiences of a Cameroon Frontier Town. Yaounde: University of Yaounde.

Achankeng, E. (1995). Mamfe: Changing Urban Growth Trends in a Cameroon Border Town Dependency or Independence? Cameroon Geographical Review, XII, 47-61.

Adams, T. M., Konoz, N. A., \& Vondorohe, A. P. (2001). Guidelines for the Implementation of Multimodal Location Referencing Systems. NCHRP Report 460, Transportation Research Board, National Research Council, Washington DC: National Academy Press.

ADB Group (2014). Transport in Africa. The African Development Bank's Intervention and Results for the Last Decade (130 p). Summary Evaluation Report, ADB Group. http://idev.afdb.org/en/document/transport-africa-african-development-bank\%E2\%80 \%99s-intervention-and-results-last-decade

ADB/UNECA (2003). Review of the Implementation Status of the Trans-African Highways and Missing Links (Vol. 1, p. 58). Description of Corridors.

Ashu, A. A. (2004). The Role and Impact of the Nigerian Trading Activities in Mamfe 1922-62 (119 p). Yaoundé: University of Yaoundé I.

Barr, B. et al. (1972). Some Spatial Interpretations of Alternative Optimal, and Sub Optimal Solutions to the Transportation Problems. Canadian Geographer, 16, 356-364.

BUCREP (2005). Recensement Général de l'Habitat de Population du Cameroun (RGHP) 2005 with Projections (BUCREP). Yaounde, Cameroon.

Cupers, K., \& Meier, P. (2020). Infrastructure between Statehood and Selfhood: The Trans-African Highway. The Journal of the Society of Architectural Historians, 79, 61-81. https://online.ucpress.edu/jsah/article/79/1/61/106913/Infrastructure-between-Stateho od-and-Selfhood-The

Donaldson, D., Jinhage, A., \& Verhoogen, E. (2017). Beyond Borders: Making Transport Work for African Trade (8 p). International Growth Centre (IGC).

https://www.theigc.org/wp-content/uploads/2017/03/TransportGrowthBrief_FINAL_ WEB.pdf

Enoh Oben, V. (1987). Politics, Power and Authority among the Stateless sociEties of Manyu Division: The Case of Bayang and Keaka under German and British Rule. Yaounde: University of Yaounde.

Environmental Protection Agency (1997). Evaluation of Modeling Tools for Assessing Land Use Policies and Strategies. EPA 420-R-97-007, Ann Arbor, MI: EPA.

Etamba Eta, T. (1999). The Impact of Colonisation on the Bayang Clan 1888-1961. Yaounde: University of Yaounde 1.

EU's European Development Fund for ACP Group of States (2012). Implementation of 
the Support to the Transport Sector Development Programme: Lot 1 Support to the AUC Department of Infrastructure and Energy in Transport Policy Harmonization and Transport Sector Services Development \& Support to PIDA PAP for the Start-Up of Smart Corridor Activities (83 p).

https://au.int/web/sites/default/files/newsevents/workingdocuments/31372-wd-lot_1_t ransport_policy_paper_updated_1409.pdf

Everson, J. A. et al. (1972). Concepts in Geography. 3 Inside the City (239 p). London: Longman Group Limited.

Ministry of Economy, Planning and Regional Development (MINEPAT) (2010). Strategic Document for Growth and Employment in Cameroon (167 p). Yaounde.

Ndi, A. (2013a). Southern West Cameroon Revisited 1950-1972. Cameroon: Langaa RPCIG.

Ndi, A. (2013b). Southern West Cameroon Revisited: North-South West Nexus, 1858-1972, Myth, History and Reality (Vol. 2). Bamenda: Paul's Press.

Ngwa Nebasina, E. (1997). Resettling African Village Communities. Performance Structures for a Better Socio-Economic Developmental Approach. Review De Géographie Du Cameroun, Vol. 13, Department of Geography, University of Yaounde 1, Yaounde.

Nwana. O. C. (1982). Introduction to Educational Research. Ibadan: Heinemann Educational Books.

O'Kelly, M. E. (1998). A Geographers Analysis of Hub and Spoke Networks. Journal of Transport Geography, 6, 171-186.

Porter, G. (2012). Reflections on a Century of Road Transport Developments in West Africa and Their (Gendered) Impacts on the Rural Poor. EchoGeo, 20, 1-14. https://pdfs.semanticscholar.org/82c6/9c5c15b381f243a7402ef8b909d0005958d7.pdf?= ga $=2.120940296 .1022263823 .1597832577-621017268.1573463231$

Sera, B. (1975). Cocoa, Custom, and Socio-Economic Change in Rural Western Nigeria. Oxford: Clarendon press.

Teravaninthorn, S., \& Raballand, G. (2009). Transport Prices and Costs in Africa, a Review of the Main International Corridors (166 p). Washington DC: World Bank. https://openknowledge.worldbank.org/bitstream/handle/10986/6610/461810PUB0Box 3101OFFICIAL0USE0ONLY1.pdf? sequence $=1$ \&isAllowed $=\mathrm{y}$

Tranche, B. F. (2018). Road Transport in Africa. Analysis and Appeal for Innovation. In CasamanSun Proceedings, Ziguinchor, Senegal, 3-5 May 2018, 8 p. https://www.researchgate.net/publication/324759369_Road_transport_in_Africa_Anal ysis_and_appeal_for_innovation

UN Economic and Social Council (UNESC), Commission for Africa (ECA) (2009). Africa Review Report on Transport, a Summary (23 p). Addis Ababa, Ethiopia. https://sustainabledevelopment.un.org/content/documents/AfricanReviewReport-on-T ransportSummary.pdf

Wikipedia (2013). https://en.wikipedia.org/wiki/Category:Road_transport_in_Africa 